\title{
A PROVA NO PROCESSO CIVIL: DO CÓDIGO DE 1.973 AO NOVO CÓDIGO CIVIL
}

Leonardo Greco

SUMARIO: 1. Introdução. 2. Sistemas probatórios e verdade histórica e científica. 3. Meios de Prova. 4. A prova como direito. 5. Juiz inerte, juiz autoritário ou juiz ativo. 6. Onus da Prova. 7. Livre convencimento. 8. Provas legais e limitações probatórias. 9. Proibição de provas ilícitas. 10. Presunçốes. 11. Fatos notórios. 12. Fatos confessados e incontroversos. 13. Confissão. 14. Prova documental. 15. Prova testemunhal. 16. Prova científica.17. Conclusão. 18. Bibliografia.

SUMMARY: 1. Introduction. 2. Systems probatories and scientific and historical truth. 3. Meanses of evidence. 4. The evidence like right. 5. Inert judge, authoritarian judge or active judge. 6. Responsability of evidence 7. Free argument. 8. Evidence lawful and limitations probatories. 9. Prohibition of evidences illicit. 10. Presumptions. 11. Notorious facts. 12. Facts confessed and uncontroverted. 13. Confession. 14. Evidence documental. 15. Evidence testemunhal. 16. Evidence scientific. 17. Conclusion. 18. Bibliography.

SUMARIO: 1. Introducción. 2. Probatories de sistemas y verdad científica e histórica. 3. Meios de la evidencia. 4. La evidencia como el derecho. 5. El juez inerte, el juez autoritario o el juez activo. 6. Responsabidad de la evidencia. 7. El libre convencimento. 8. Evidencia lícita y limitaciones probatorias. 9. La prohibicion de evidencias ilícitas. 10. Las presunciones. 11. Los hechos notorios. 12. Los hechos confesaron y uncontroverted. 13. La confesión. 14. Evidencia documental. 15. Evidencia testemunhal. 16. Evidencia científico. 17. Conclusión. 18. Biblografia. 
RESUMO: O presente artigo trata das questóes do direito probatório mais relevantes e passíveis de uma abordagem mais simples. Sem que nós tivéssemos percebido, o direito probatório banhou-se de valores humanitários, muitos dos quais de alcance ainda impreciso. O desenvolvimento tecnológico pode desmaterializar a prova de muitas relações jurídicas e o próprio processo judicial, como vem crescentemente ocorrendo. O novo Código Civil, concebido a mesma época do Código de 1973, parece pretender ressuscitar a estéril polêmica sobre a natureza das normas probatórias, sobrepondo regras suas às da legislação processual e ignorando por completo o caráter humanitário assumido pelo direito probatório e o impacto que lhe causa o desenvolvimento tecnológico, fenômenos desconhecidos ou pouco relevantes à época da sua concepcão e por ele quase totalmente ignorados. As disposições probatórias devem ser inter pretadas de modo a assegurar a mais ampla eficácia das garantias fundamentais do processo, constitucionalmente reconhecidas, pois, se isso não for possivel, deverão ser repudiadas por inconstitucionalidade.

ABSTRACT: The present article tries the questions of the right probatory more prominent and simpler. Without that we had perceived, the right probatory bathed worthy humane, many of the which of reach still inexact. The technological development is able to over the evidence of many legal relations and the own judicial process. The new Civil Code, conceived to the same epoch of the Code of 1973, tries the polemics about the nature of the norms probatories, against its rules to the from the legislation processual and ignoring completely the humane character assume by the right probatory and the impact that the technological development causes him, phenomena unknown or little prominent to the epoch from the its conception and by. The arrangements probatories should be interpreted of way it assure to broader efficacy of the fundamental guarantees of the trial, constitutionally recognized, therefore, if that will not go possible, they should be disowned by against Constitution. 
RESUMEN: El artículo trata del probatorio más prominente y más sencillo. Sin que habíamos percibido, el probatory se bañó digno humano, muchos del cuál de alcance todavía inexacto. EI desarrollo tecnológico es capaz de desmaterializar la evidencia de muchas relaciones legales y el propio proceso judicial. El Código Civil nuevo, concebido a la misma época del Código de 1973, prueba el polémico acerca de la naturaleza de las normas probatorias, contra sus reglas al del processual de la legislación e ignorando completamente el carácter humano asumido por el directo probatorio y el impacto que el desarrollo tecnológico lo causa, los fenómenos desconocidos o pequeños prominentes a la época de la su concepción. Las probatorias se debe interpretar de la manera que lo asegura la eficacia más ancha de las garantías fundamentales del ensayo, constitucionalmente reconocido, por lo tanto, si eso no irá posible, ellos deben ser repudiados por contra Constitución.

PALAVRAS-CHAVE: Meios de Prova. Código de Processo Civil. Código Civil. Ónus da Prova.

KEY-WORDS: Meanses of evidence. Civil Suit Code. Civil Code. Responsability of evidence.

PALAVRAS-LLAVES: Meios de la evidencia. El Código de el proceso civil. El Código civil. Responsabilidad de la evidencia.

\section{Introdução}

Em matéria probatória, o Código de Processo Civil de 1973 procurou refletir a doutrina dominante à época, superando a infindável polêmica sobre a natureza material ou processual das normas probatórias através da regra acolhedora do artigo 332, que incorpora ao direito processual todos os meios de prova previstos em leis substanciais, e reproduzindo disposiçóes consagradas em outros sistemas jurídicos, especialmente o italiano, dos quais sofreu notória influência.

Mas o Código de 1973 representou nessa matéria, como em muitas outras, o apogeu do processualismo científico, preocupado em definir 
com clareza o papel de cada um dos sujeitos do processo e em analisar os pressupostos de validade e a eficácia dos atos probatórios por eles praticados, bem como a sua inserção nos diversos procedimentos.

Sob esses aspectos, o Código sobrevive como obra exemplar e duradoura, e as poucas reformas que sofreu não abalaram a solidez das suas disposições, nem tampouco introduziram aprimoramentos significativos.

Sobrevindo a Constituição de 1988, o Brasil reconstrói o seu Estado de Direito, adotando como pedra fundamental o primado dos direitos fundamentais, entre eles o de amplo acesso a um tribunal independente previamente instituído pela lei para a tutela de qualquer direito lesado ou ameaçado (art. $5^{\circ}$, inciso XXXV).

Surgem, ou são objetivamente explicitados, novos direitos da pessoa humana, como o direito à intimidade e à vida privada e, no âmbito do processo, a ampla defesa e o contraditório deixam de ser proclamaçôes vazias para adquirir concretude através do direito a defender-se provando, do direito à igualdade concreta, ao contraditório participativo e ao mais amplo respeito à dignidade humana, claramente representado pela proibição das provas ilícitas.

A eficácia imediata e concreta dos direitos subjetivos reconhecidos pela lei, de que é expressão o $\$ 1^{\circ}$ do art. $5^{\circ}$ da Carta Magna, somente se realiza com o abandono de regras probatórias abusivamente limitadoras da busca da verdade objetiva, pois o direito material não pode dar com uma mão e o processo tirar com a outra, ou seja, o direito material não pode reconhecer determinado direito a quem provar determinado fato e o direito processual impedir que o interessado prove em juizo a existência desse fato.

O método processual de busca da verdade vai aos poucos se aproximando do método histórico e do método científico e a livre convicção não pode transformar-se em instrumento de arbítrio, nem tampouco convencer apenas ao próprio juiz.

Sem que nós tivéssemos percebido, o direito probatório banhou-se de valores humanitários, muitos dos quais de alcance ainda impreciso.

Por outro lado, ninguém podia prever que o desenvolvimento tecnológico pudesse desmaterializar a prova de muitas relações jurídicas e o próprio processo judicial, como vem crescentemente ocorrendo.

Nesse clima, surge o novo Código Civil, concebido à mesma época do Código de 1.973, e, como a tentar fazer o relógio andar para trás, parece pretender ressuscitar a estéril polêmica sobre a natureza das normas 
probatórias, sobrepondo regras suas às da legislação processual e ignorando por completo o caráter humanitário assumido pelo direito probatório e o impacto que lhe causa o desenvolvimento tecnológico, fenômenos desconhecidos ou pouco relevantes à época da sua concepção e por ele quase totalmente ignorados.

As suas disposições não podem ser simplesmente confrontadas com as do Código de Processo, como se o Código de 2002 tivesse regulado inteiramente a matéria. Dos meios de prova em espécie contém apenas algumas disposições esparsas que se sobrepõem, conciliando-se com as do Código de 73 e complementado-as ${ }^{1}$. A derrogação ou a revogação das regras deste por aquele, entretanto, deve reconhecer-se apenas nos casos de direta incompatibilidade.

Por outro lado, as disposições probatórias de um e outro Códigos devem ser interpretadas de modo a assegurar a mais ampla eficácia das garantias fundamentais do processo, constitucionalmente reconhecidas, pois, se isso não for possível, deverão ser repudiadas por inconstitucionalidade.

Tentarei, à luz dessas circunstâncias, abordar as questões do direito probatório que me parecem mais relevantes e passíveis de uma abordagem mais simples, deixando, quiçá, para outro momento, outras de maior complexidade.

\section{Sistemas probatórios e verdade histórica e científica}

$\mathrm{Na}$ busca de parâmetros tendencialmente universais de acesso à Justiça tem-se intensificado o diálogo entre as duas principais famílias de sistemas jurídicos, as dos países da common law e da civil law. Entretanto, as diferenças entre os dois sistemas probatórios são sensíveis e a sua análise servirá para mostrar muitas deficiências do nosso ordenamento, cuja superação certamente constitui enorme desafio para os juristas, assim como para evidenciar que, embora o Direito brasileiro pertença à família do Direito Romano-Germânico, à também chamada civil law, que é o Direito continental europeu, vem sofrendo influências crescentes do Direito norte-americano, até de modo inconsciente, fazendo-se necessário compreender, entretanto, a diversidade cultural existente entre as

${ }^{1}$ V. José Carlos Barbosa Moreira, "O novo Código Civil e o Direito Processual", in Revista Forense, Rio de Janeiro, $\mathrm{n}^{\circ} 364,2003$, págs. 181 e ss. 
duas famílias e a diversidade de valores e princípios em que se assentam as respectivas disciplinas probatórias.

NICOL TROCKER ${ }^{2}$, recordando Vittorio Denti ${ }^{3}$, resumiu etn estudo recente as características do Direito probatório dos dois sistemas. Nos países da civil law têm mais valor as provas escritas (documental e pericial), em detrimento da prova testemunhal; há uma tendência à atenuação progressiva das provas legais, ao fortalecimento do livre convencimento do juiz e ao aumento dos poderes do juiz na pesquisa da verdade, enfraquecendo-se a sua dependência em relação à iniciativa probatória das partes, às quais se reconhece o direito de não produzir provas em seu prejuízo. Diversamente, nos países da common law, apesar de recentes reações, a iniciativa probatória é quase exclusiva das partes; há uma especial valorização das provas orais colhidas sob contraditório através da cross examination (inclusive o depoimento pessoal das partes e a prova pericial) e do dever de colaboração das partes na apuração da verdade, este revelado especialmente pelo instituto da discovery, que obriga cada uma das partes a produzir provas de interesse da outra, até mesmo a respeito de fatos aparentemente irrelevantes, sob pena de sanções rigorosas (contempt of court). O juízo de admissibilidade da prova somente vai ocorrer na fase do trial, depois que a prova já foi recolhida através da discovery na fase do pre-trial, na qual as partes não tiveram de definir com clareza os fatos que pretendetiam provar. $\mathrm{Na}$ ausência de uma efetiva exigência de colaboração das partes, cuja liberdade e privacidade são muito respeitadas, os países da civil law supervalorizam as regras de distribuição do ônus da prova. A intimidade é mais intensamente protegida nos sistemas da civil law do que nos da common law. As escusas probatórias são mais acentuadas naqueles, com fundamento no sigilo profissional e no risco de sofrer grave dano, além da proteção do sigilo bancário e comercial, enquanto na common law é reduzida a importância da privacidade documental ${ }^{4}$.

\footnotetext{
"Nicolò Trocker, "Il contenzioso transnazoinale e il diritto delle prove", in Rivista Trimestrale di Dirito e Procedura Civile, ano XLVI, 1992, Giuffé, Milano, págs. 475 e $5 s$. "Vittorio Denti, "La evolución del derecho de las prubas em los procesos civiles contemporáneos", in Estudios de derecho probatorio, EJEA, Buenos Aires, 1974 , págs.77 e $\$$ s. - V. tambem Mauro Cappelletti, Procedure Orale et Procedure Ecrite, Guffrè, Milano, 1971; Michele Taruffo, "Modelli di prova e di procedimento probatorio", in Rivista di Dirtto Processuale CEDAM, Padova, 1990 , págs 420 e ss.
} 
Essa comparação evidencia que, de um lado, o sistema da common law se apresenta mais apto à apuração da verdade, enquanto o sistema da civil lawé mais respeitoso da dignidade humana e dos direitos da personalidade, o que me levaria a acreditar que o ideal de um processo justo exigiria que, da fusão dos dois sistemas, pudessem ser aproveitados esses seus dois grandes méritos.

$\mathrm{Na}$ elucidação dos fatos, seria necessário examinar a conveniência de eliminar do sistema probatório todas as restrições à apuração da verdade, sejam as que priorizam determinadas provas em detrimento de outras, sejam as impostas pela marcha do processo, salvo as ditadas pelo respeito à dignidade humana, para que a verdade judicial pudesse aproximar-se o mais possível da verdade histórica e da verdade científica.

Nessa aproximação, todavia, emergem novos problemas, como o próprio caráter polêmico que vai impregnando o conhecimento histórico e o conhecimento científico, mesmo nas ciências mais estritamente racionais, como a física, a química e a matemática e a crescente necessidade de o processo, mesmo sem abandonar a sua preocupação com a segurança jurídica, poder precaver-se ou amoldar-se às mutações constantes do estado da técnica, que a todo tempo descobre um novo saber, que desmente a verdade científica mais categórica de um passado recente.

\section{Meios de Prova}

Em manifesta vantagem sobre o Código de 39, que no artigo 208 admitia "todas as espécies de provas reconhecidas nas leis civis e comerciais", ignorando as leis tributárias, as administrativas e tantas outras, o art. 332 do Código de 73 passou a aceitar todos os meios legais, independentemente da natureza da norma instituidora (civil, comercial, administrativa, tributária, trabalhista, processual etc.), acrescentando-lhes ainda "os moralmente legítimos"s.

Estes últimos, inicialmente percebidos como extensivos a provas inominadas, como a prova emprestada ${ }^{6}$, com a emergência do primado dos direitos fundamentais foram associados à proibição das provas ilícitas, ainda que nominadas ${ }^{7}$. Essa evolução só foi possível graças à juridicização, através dos chamados direitos da personalidade, de uma

\footnotetext{
${ }^{5}$ Moacyr Amaral Santos, Comentarios ao Codigo de Processo Civil, IV vol., 20 ed., Forense, Rio, 1977 , pág. 26 .

" Moncyr Amaral Santos, ob.cit., pág.27.

7 Vicente Greco Filho, Direto Processual Civil Brisileiro, 2 vol., 15\% ed., Saraiva, São Panlo, 2002, píg.185.
} 
série de regras morais protetivas da honra, da vida privada, do pudor, da imagem, da liberdade de consciência etc.

O novo Código Civil (art.212) passa ao largo dessa questão, referindose apenas, como meios de prova, e ressalvado o negócio jurídico que exija forma especial, à confissão, aos documentos, às testemunhas, às perícias e às presunções. Essa enumeração não se choca com a do Código de 73, sem dúvida mais completa por incluir a inspeção judicial e as provas inominadas e, portanto, mais favorecedora da apuração da verdade objetiva, valor humanitário respaldado na Constituição, que, conforme já acentuei, impõe uma interpretação harmonizadora.

\section{A prova como direito}

No momento em que foi concebido o Código de 73 , prevalecia o entendimento de que, sendo o juiz o destinatário das provas, cabia-lhe com exclusividade decidir a respeito da sua admissão.

Escrevia MOACYR AMARAL SANTOS:

A admissão (das provas) é ato do juiz, exclusivamente seu. Como ó a avaliação ou estimação da prova".

Às partes caberia, no máximo, fiscalizar eventual abuso do juiz, que arbitrariamente, sem justificativa, deferisse ou indeferisse determinada prova.

Essa concepção está refletida em diversos dispositivos do Código, a começar pelo art. 130, que atribui ao juiz a determinação ex-officio das "provas necessárias à instrução do processo, indeferindo as diligências inúteis ou meramente protelatórias".

Igualmente em outros dispositivos, o uso do verbo poder sugere que o juiz discricionariamente venha a determinar ou não a produção destas ou daquelas provas, num juízo de valor estritamente pessoal a que não corresponderia nenhum direito subjetivo das partes. Assim, no art. 342 sobre o depoimento pessoal, no art. 355 sobre a exibição de documento ou coisa, no art. 418 sobre a acareação e a inquirição de testemunhas referidas, no art 437 sobre a segunda perícia e no art. 440 sobre a inspeção judicial.

Essa concepção evoluiu, desde então, sob influência do moderno alcance das garantias constitucionais do contraditório e da ampla defesa.

\footnotetext{
" Moayr Amaral Santos, Prova Judiciaria no Civel e Comercial, vol. 1, s/d, ed. Max Limonad, pág.255;

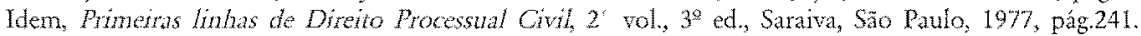


O contraditório participativo, como o princípio que assegura aos interessados o direito de influir eficazmente nas decisões judiciais, e a ampla defesa, como "o direito de apresentar todas as alegações, propor e produzir toda as provas que, a seu juizo, possam militar a favor do acolhimento da sua pretensão ou do não acolhimento da postulação do seu advexsário", conferem às partes o direito de defender-se provando, ou seja, o direito de não apenas propor provas a serem discricionariamente admitidas ou não pelo juiz, mas de efetivamente produzir todas as provas que possam ser úteis à defesa dos seus interesses. Para assegurar esse direito $e$, ao mesmo tempo, velar pela rápida solução do litígio e coibir a realização de diligências inúteis ou protelatórias (CPC, arts. 125-II e 130), é necessário que a admissibilidade das provas seja apreciada pelo juiz não da sua própria perspectiva, mas da utilidade ou relevância da prova, analisada à luz da perspectiva probatória ou da linha de argumentação da parte que a propôs. Se desse prisma resultar que a prova requerida possa ter alguma utilidade, o juiz deverá deferi-la, indeferindo apenas aquelas provas que, nem mesmo por esse critério, possam apresentar a mais remota utilidade. Na dúvida, o juiz deverá ser tolerante, deferindo a prova requerida, cuja admissibilidade deve significar não manifesta irrelevância ou inutilidade. Somente assim o juiz despir-se-á de um juízo de admissibilidade autoritário e preconceituoso.

Nem se diga que esse novo paradigma poderá vir a prejudicar a celeridade do processo, transformando o juiz num fantoche nas mãos das partes, porque essa compreensão humanitária e tolerante da relação juiz-partes se completa com as modernas técnicas de antecipação de tutela que permitem ao julgador, já convencido do direito do autor, antecipar em seu favor os efeitos da sentença de mérito, sem prejuízo da continuidade do processo em benefício da mais ampla possibilidade conferida ao réu de demonstrar que tem razão ${ }^{10}$.

\footnotetext{
"V. o item 1.3. do meu estudo Garantias Futudamentais do Processo o Processo Justo, publicado na revista Novos Estudos Jurídicos, ano VI, na 14, abril/2002, revista semestral do Curso de Pós-Graduação stricto sensu em Ciêtucias Juridicas da Universiade do Vale do TtajátUNTVLL; também publicado na revista Argunenta, n"2, 2002, do Programa de Mestrado em Ciencia Juridica da Faculdado Estadual de Direito do Norte Pioneiro, de Jacarezinho, Paraná, págs. 32/95; e na Revista Juridica, ano 51. março de 2003, $n^{\circ}$ 305, ed. Notadez, São Paulo, págs. 61/99. in V. Luiz Fux, Tutela de Segurança e Tutel da Evidencia, Saraiva, São Paulo, 1996, págs. 305 e ss..
} 


\section{Juiz inerte, juiz autoritário ou juiz ativo}

O Código de 1.973 representou no Brasil uma das últimas manifestaçóes de crença na infalível supremacia do interesse público sobre o interesse particular e na excelência do Estado-Providência, paternalista e interventivo.

Esse modelo, que desmoronou em todo a Europa continental desde o término da $2^{\circ}$ Grande Guerra, porque se tornou instrumento dócil dos piores regimes autoritários, pregava o abandono do princípio dispositivo e a outorga ao juiz de amplos poderes de determinar de oficio todas as provas necessárias à formação do seu convencimento, mesmo nas causas que versassem sobre interesses disponíveis.

Foi essa a fonte de inspiração do artigo 130 do Código de 73 , que reproduziu o artigo 117 do Código de 39 , acreditando que a outorga de poderes inquisitórios ao juiz pudesse contribuir para a certeza da busca da verdade objetiva e de decisões mais justas.

Essa crença no juiz-super homem desapareceu por completo. Se é correto que o simples entrechoque dos fatos e provas apresentados pelas partes não assegura a descoberta da verdade, porque cada uma das partes tende a revelar apenas as circunstâncias que the são favoráveis, por outro lado, a busca frenética da verdade absoluta pelo juiz, além de comprometer a sua imparcialidade e de cercear a liberdade individual, não garante que o resultado obtido seja melhor do que o que teriam alcançado os próprios interessados.

Ao juiz inerte, como tradicionalmente no adversarial system, e ao juiz autoritário e inquisidor, o Führer do processo, deve opor-se o juiz democrático, que respeita a liberdade das partes na iniciativa probatória na medida em que elas se presumem encontrar-se na posição ideal para avaliar a relevância e utilidade de cada prova em relação à sua versão dos fatos. Mas o juiz democrático é aquele que, através da maiêutica, consegue estabelecer um diálogo humano com as partes, que permite que estas efetivamente acompanhem o desenvolvimento da formação da sua convicção e assim possam propor e produzir provas úteis e relevantes, e que somente intervém subsidiariamente na proposição de provas por elas năo requeridas, quando se fizer necessário, para assegurar a paridade de armas, suprir a dificuldade em que uma delas se encontre no exercício dos seus meios de defesa, em razão da inferioridade no acesso a esses 
meios em relação à outra, ou em razão da desídia ou inércia do seu advogado ou até mesmo da impossibilidade de descobrir que provas poderiam vir a gerar a conviç̧ão do juiz. Essa iniciativa subsidiária faz-se necessária também para assegurar a consistência da reconstrução da verdade histórica, muitas vezes insuficientemente fundamentada nas provas produzidas pelas partes.

E o juiz, moderada e parcimoniosamente ativo, que, nas causas que versam sobre dircitos disponíveis, usa as faculdades do art. 130 em caráter subsidiário das partes; já nas causas que versam sobre direitos indisponíveis, sem ir em busca de uma utópica e inatingivel verdade real, deve determinar a produção de tantas provas quantas sejam necessárias para evitar que uma das partes ou ambas venham a abrir mão de direito do qual não possam dispor ${ }^{11}$. Em qualquer caso, através do diálogo humano, policia a formação de juízos preconceituosos.

\section{Onus da Prova}

As regras de distribuição do ônus da prova têm duplo objetivo: primeiramente definir a qual das partes compete provar determinado fato, o chamado ônus subjetivo; em seguida, no momento da sentença, servir de diretriz no encadeamento lógico do julgamento das questões de fato, fazendo o juízo pender em favor de uma ou de outra parte conforme tenham ou não resultado provados os fatos que a cada uma delas interessam, o chamado onus objetivo.

O art. 333 do Código de Processo Civil reproduz as regras clássicas de distribuição do ônus da prova: ao autor, os fatos constitutivos do seu direito; ao réu, os fatos extintivos, modificativos ou impeditivos do direito do autor. Fica afastado desde logo o caráter imperativo dessas regras, pois o parágrafo único do mesmo artigo permite a sua derrogação convencional, salvo se recair sobre direito indisponível ou se a convenção tornar excessivamente dificil a uma parte o exercício do direito.

Por outro lado, muitas vezes a inexistência de um fato constitutivo é um fato impeditivo, extintivo ou modificativo. Se estes últimos são a

\footnotetext{
"Juan Montero Aroca (Los principios politicos de la nueva Ley de Enjuicimiento Civit Los poderes del juez y la onalidad, Tirant lo Blanch, Valencia, 2001, pág. 112) atribui a Camelutti ter destrúdo o mito da verdade formal, evidenciando que a verdade é uma só on a verdade formal coincide com a verdade material, não sendo mais do que simplesmente a verdade, ou com ela conflita, caso en que é apenas uma não verdade.
} 
chamada causa excipiendi, ou seja, o direito do réu que se opõe ou que ilide o direito do autor, cumpre reconhecer que a inexistência do direito do autor pode ser elemento constitutivo do direito do réu. Assim, por exemplo, no contrato de locação, a omissão do pagamento dos aluguéis pelo inquilino é fato constitutivo do direito do locador à rescisão do contrato, mas o inverso, o pagamento, é fato extintivo do direito do autor, que ilide o pedido de rescisão do contrato. Pode impor-se ao autor o ônus de provar o inadimplemento contratual do locatário ou cabe ao réu a prova do seu cumprimento?

Ademais, algumas teorias têm sido desenvolvidas para justificar a flexibilização das regras sobre o ônus da prova, como a da Anscheinsbeweis (prova da aparência) ou a da Wahrscheinlichkeit (juízo de verossimilhança) que, através de presunções simples levam à inversão do ônus da prova em inúmeras situações ${ }^{12}$.

Por isso, a tendência moderna é reconhecer o que JUAN MONTERO AROCA denomina, com base no art. 217.6 da nova Ley de Enjuiciamiento Civil espanhola de 2.000 de critério da disponibilidade e facilidade probatória ${ }^{13}$, que vai impor o ônus da prova não com base em critérios teóricos, mas com base na proximidade real em que as partes se encontrem em relação às fontes de prova. Se as provas estão em poder do demandado ou ao seu alcance, pode constituir um ônus excessivo exigir do autor que as proponha ou produza.

Ademais, é condenar a parte previamente à perda do seu direito, obrigála a provar afirmações ou negaçōes genéricas. O sempre lúcido MOACYR AMARAL SANTOS chamava a essas hipóteses de negativas ou afirmações indefinidas: "Dificilimo será a Caio provar que nunca foi a Santos, como lhe será dificilimo provar que permanentemente usou determinada jóia"14.

Convencendo-se, pelas circunstâncias do caso concreto, que as regras legais de distribuição do ônus da prova tornarão excessivamente onerosa a prova da existência do direito pela parte a quem aproveita, deverá o juiz, em respeito às garantias constitucionais do contraditório e da ampla defesa e, particularmente, à igualdade concreta de que devem desfrutar as partes no acesso à Justiça, inverter o ônus da prova, exigindo da parte que está em condiçōes mais favoráveis a prova do fato contrário, evi-

12 V. Michele Tarufo, "Presunzioni, inversioni, prova del fatto", in Rivista Trinestrale di Dirito e Procedura Civile, Guffrè, Milano, ano XIVI, 1992, págs.733 e ss..

"Juan Montero Aroca at ali, Desecho Jurisdiccional, vol. II, $10^{\circ} \mathrm{ed}$., Tirant lo Blanch, Valencia, 2001, pág. 260 .

${ }^{14}$ Prineinas Linhas, $2 *$ vol., pág 305. 
dentemente, após intimá-la da inversão e dar-lhe ampla oportunidade de desenvolver as atividades necessárias ao cumprimento desse novo ônus. Ao contrário do que se pode pensar, a regra do art. $6^{\circ}$, inciso VIII, do Código de Defesa do Consumidor não é privativa das relações de consumo, aplicando-se a todas as hipóteses em que as regras do art. 333 do CPC venham a gerar uma concreta desigualdade entre as partes ou tornar excessivamente onerosa a demonstração da verdade fática que a uma delas interessa.

Haverá casos em que não despontará com clareza a maior facilidade do adversário de apresentar a prova esclarecedora da ocorrência de determinado fato, mas em que estará de qualquer modo patente a incapacidade in concreto do próprio interessado em conhecê-la ou produzi-la, caso em que o próprio juiz deverá suprir essa deficiência com a determinação de ofício da produção da prova, com arrimo no art. 130 do CPC.

\section{Livre convencimento}

O art. 131 do Código de Processo Civil faculta ao juiz a livre apreciação das provas, desde que ele enuncie na sua decisão as razões que o determinaram. Embora a mais autorizada doutrina da época do Código já alertasse para o perigo do arbítrio daí decorrente ${ }^{15}$, prevaleceu o entendimento de que o dever de fundamentação serviria apenas para dar consistência lógica à decisão e para atestar o seu embasamento no material probatório produzido no processo, sem afetar a liberdade de julgamento do juiz ${ }^{16}$.

A tutela jurisdicional efetiva dos direitos dos cidadãos, constitucionalmente assegurada (art. $5^{\circ} \mathrm{XXXV}$ ), não se contenta com qualquer verdade fática, emanada da opinião do julgador, o que transformaria o direito subjetivo em um direito aleatório, conforme os fatos dos quais resulta fossem reputados ou não verdadeiros pelo julgador. Se diante de certas provas, determinado cidadão teve reconhecidos como verdadeiros os fatos de que resulta o seu direito, diante dessas mesmas provas um outro juiz não pode recusar essa veracidade, simplesmente porque o primeiro juiz se convenceu da existência dos fatos e o segundo, não.

A administração da justiça não pode ser uma loteria.

Com razão, GIAN FRANCO RICCI ${ }^{17}$ assinala que o acertamento da

\footnotetext{
${ }_{15}$ V. Moacyr Amaral Santos, Prineiras Linhas, pág.333.

16 Vicente Greco Filho, ob.cit., pág.198.

${ }^{17}$ Gian Franco Ricci, "Nuovi rilievi sul problema della 'specificità' della prova giuridica" in Rivista Trimcstrale di Diritto e Procedura Civile, ano LIV, 2000, Giuffrè, Milano, págs.1137/1141.
} 
verdade deve ser pelo menos o modo, e quiçá o único modo, através do qual o processo deve atingir os seus fins. Esse acertamento deve ser demonstrativo, e não simplesmente retórico, baseado em argumentos rigidamente racionais, e não em preferências pessoais do julgador, através da fundamentação lógica pela qual os fatos são extraídos das provas. E, citando Calamandrei e Taruffo, observa que o acertamento verdadeiro dos fatos inclui-se entre os escopos institucionais do processo, pois o distanciamento entre o processo e a justiça aparece como um desvio totalmente inatural, que corre o risco de fazer derrubar a ciência jurídica no mais completo abstratismo, o que acabaria por configurá-la ainda como o direito de não ter razão, em absoluta contraposição à garantia da tutela jurisdicional efetiva e à eficácia concreta dos direitos fundamentais, proclamadas entre nós no inciso XXXV e no $\S 1^{\circ}$ do art. $5^{\circ}$ da Constituição ${ }^{18}$.

A isonomia e a impessoalidade da jurisdição (Constituição, arts. $5^{\circ}$-I e 37) exigem que o livre convencimento seja formado através de critérios aceitáveis para todos e não apenas para o juiz. Esses critérios devem ser extraídos das máximas da experiência comum reconhecidas pela sociedade, cujo uso o juiz deve mencionar, explicando como foram aplicadas no julgamento da verdade fática, para tornar possível o controle do seu emprego adequado ${ }^{10}$. Ademais, os critérios de julgamento devem fundarse em premissas objetivamente verificáveis, e não em intuições subjetivas ou na crença de percepçóes extra-sensoriais. Por outro lado, um contraditório participativo, capaz de instaurar um fecundo e interativo diálogo humano sobre as questões de fato, é um eficaz instrumento de controle da razoabilidade das escolhas e inferências que o juiz necessitara fazer ${ }^{20}$. A teoria da argumentação, modernamente desenvolvida na filosofia, pode fornecer subsídios importantes para dar densidade lógica ao discurso judicial ${ }^{21}$ e auxiliar o julgador na valoração das hipóteses de julgamento.

Já se tornou dominante nos sistemas de common law e crescente na Europa continental, o entendimento de que quando a prova judiciária precisa recorrer ao conhecimento de ciências diversas do Direito, ela deve procurar empregar os critérios aceitos por essas ciênctas, lógica e racionalmente estabelecidos e aplicados ${ }^{22}$.

\footnotetext{
V. Michele Taruffo, La prova de fatri gividic, Giuffre, Milano, 1992, págs. 1 e ss,; Idem, Lezioni sul processo civile, 20 ed., Il Mulino, Bologna, 1998, pág.604.

Francesco P. Luiso, Dirito Processuale Civile, vol.II, $3^{\circ}$ ed., Giuffè, Milano, 2000 , pág.74.

20 Michele Taruffo, Lat prova dé fatti gíuridici, págs.401 e $\$ s$.

${ }^{21}$ V. Claudia Sevilha Monteiro, Teeria da Argumentaço Juŕdica e Nova Retórica, $2^{2}$ ed., Lumen Júris, Rio de Janeirozon3.

3. Gian Franco Ricci, ob.cit., pág. 1.132.
} 


\section{Provas legais e limitaçōes probatórias}

O Código de 73 admite que a lei, em certos casos, somente aceite certas provas para admissão da veracidade de determinados fatos. São as chamadas provas legais, que tolhem o livre convencimento do juiz, porque não permitem que o juiz aceite como verdadeiros esses fatos a não ser mediante a concreta apresentação das provas exigidas pela lei. É o que ocorre, por exemplo, com a prova dos atos da vida civil ou da propriedade imóvel através de certidão do registro competente, consoante o disposto no art. 320, inciso III.

Ao lado das provas legais, existem também as chamadas limitações probatórias, que são regras que excluem a utilização de determinadas provas em certos casos, como, por exemplo, as escusas de exibição (CPC, art.363), a não admissão da prova exclusivamente testemunhal nos contratos de valor superior a 10 salários mínimos (CPC, art. 401, e novo Código Civil, art. 227), a proibição de depor às pessoas incapazes, impedidas ou suspeitas (CPC, art. 405, e novo Código Civil, art.228), as escusas de depor (CPC, arts.347 e 406, novo Código Civil, art.229).

No primeiro caso, provas legais, a sua compatibilidade com as garantias fundamentais do processo impõe que a sua aplicação fique restrita a certos direitos cujo exercício, dentro ou fora do processo, depende do registro público do seu fato gerador. São direitos absolutos, exercitáveis erga omnes, que, através do registro público, tornam público o conhecimento da sua existência, conferindo aos seus titulares e a todos os concidadãos que com eles negociam a necessária segurança jurídica. Admitir que, além desse limite, pudesse o juiz estar vinculado à força probante de determinadas provas, violaria o direito das partes a um julgamento conforme à verdade e a própria dignidade humana do juiz, obrigado, contra a sua consciência, a reputar verdadeiros fatos de cuja existência năo se convenceu.

Quanto às limitações probatórias, segundo $\mathrm{RICCI}^{23}$, há limites que visam a repudiar provas supostamente suspeitas, como as incapacidades, impedimentos e suspeições para depor, ou a prova testemunhal em contratos de valor superior a 10 salários mínimos, ou as presunções simples nas hipóteses em que está excluída a prova testemunhal (novo Código Civil, art.230). Há outros que visam a garantir um ordenado desenvolvimento do processo, como os das preclusóes e prazos probatórios. Há, ainda, outros que visam a preservar valores constitucionais, como a intimidade, o segredo de oficio ou o segredo profissional.

\footnotetext{
2 Ob.cit, pág.1.148.
} 
Os primeiros são, na verdade, máximas da experiência comum reconhecidas pelo próprio legislador com a função de auxiliar o juiz na correta formação do seu convencimento. Devem ser aceitos como recomendações, não como regras imperativas, que o juiz deve afastar quando puder demonstrar que a realidade da vida não mais as acolhe como consistentes ou quando militarem outras circunstâncias que recomendem a aplicação de outras máximas.

Os segundos visam a assegurar a boa marcha do processo (CPC, art. 125-II) e a celeridade da prestação jurisdicional, valores ponderáveis, mas que não podem impedir o acesso à verdade se a parte interessada, de boa fé, demonstrar não ter contribuído para o retardamento da proposição ou da produção da prova (CPC, arts. 397, 485-VII e 517).

Os terceiros limites evidenciam que o ordenamento jurídico, ao lado da busca da verdade, protege igualmente outros valores, como o respeito aos direitos da personalidade, ao sentimento de família ou a outros direitos fundamentais. A verdade a todo o custo, aduz $\mathrm{RICCI}^{24}$, seria uma meta absurda, inconcebível em uma sociedade civil, com base na qual poderia justificar-se até a tortura e que reconduziria o processo à barbárie do passado. Também a investigação cientifica é obrigada a respeitar a dignidade humana.

$O$ que se pode questionar é se todas as regras que a lei institui como fundamentos de escusas probatórias encontram respaldo na necessidade de preservação de autênticos direitos da personalidade ou se, extravasando desse limite humanitário, são desvirtuados no sentido de simplesmente obstarem a apuração da verdade. Essa suspeita se acentua pela falta de homogeneidade da descrição legal dessas escusas, como se verifica do disposto nos arts. 347,363 e 406 do CPC. Nessa matéria, pelo caráter restritivo do direito à busca da verdade, não pode caber qualquer arbitrio judicial, como indevidamente preconiza o inciso $\mathrm{V}$ do art. 363 , pois ao juiz não cabe por um suposto juízo de eqüidade privar o litigante do acesso à prova.

\section{Proibição de provas ilícitas}

Alheio a uma construção jurídica mais consistente, o Código de 1.973 juridicizou a proibição de provas ilícitas a contrario sensu, ao admitir as provas inominadas ou atípicas desde que "moralmente legítimas". 
Esse enunciado apresentou-se desde o início francamente insatisfatório, não somente pela impossibilidade de estabelecer em que medida a moral poderia constituir limite à admissibilidade da prova, mas também porque mesmo através dos meios legalmente previstos a prova pode ser imoral ou ilícita.

Introduzida na Constituição de 1988 a proibição das provas ilícitas (art. $5^{4}$, inciso LVI), firmou-se na doutrina e na jurisprudência a concepção que identifica as provas ilicitas com a violação de direitos fundamentais, especialmente de direitos da personalidade.

A ausência de uma lei definidora dos direitos da personalidade levou a doutrina e a jurisprudência brasileira a tatearem em avanços e recuos, ora influenciadas pelo Direito norte-americano, ora pelo Direito europeu, que possuem concepções diversas a respeito da intimidade e do próprio direito probatório ${ }^{25}$.

Deixando à doutrina e à jurisprudência a delimitação do seu conteúdo, o novo Código Civil (arts. 11/21), de modo inteiramente insatisfatório, se limita a algumas disposições de alcance geral, tão primárias quanto genéricas, porque não poderão ser aplicadas a cada um dos direitos que compõem esse universo sem uma definição clara dos seus caracteres, a tratar de alguns desses direitos em espécie, como o direito ao nome, à imagem, ao corpo vivo e ao corpo morto e a incorporar algumas regras constantes de legislação extravagante sobre temas específicos, como o transplante de órgãos.

A aplicação do princípio da proporcionalidade para admitir ou não a produção das provas ilícitas nem sempre é um critério seguro, porque a falta de uma clara hierarquia entre os direitos fundamentais, salvo os mais relevantes, como a vida, a integridade física, reduz em grande parte a discussão à ponderação in concreto dos interesses em conflito, onde são inevitáveis o casuísmo e uma grande dose de arbítrio ${ }^{26}$.

Por outro lado, o conflito entre o interesse individual e o interesse público não pode resolver-se sistematicamente em favor do segundo, sob pena de sufocação completa da liberdade humana. A prévia autorização judicial, exigida expressamente no texto constitucional apenas para a interceptação telefônica necessária à investigação criminal, deve constituir-se em princípio geral (art. $5^{\circ}$, inciso XII) nesses casos, sob pena de restabelecimento de um Estado policial.

\footnotetext{
${ }^{25}$ V. Nicolò Trocker, Processo Civile e Costituzione, Giuffè̀, Milano, 1974, págs.563 a 635; do mesmo autor, "Il contenzioso transnazionale e il diritro delle prove", in Rivista Trimestrale di Dirito e Procedura Civile, ano XLY, 1992, Giufftè, Milano, págs. 475 e ss.

${ }^{24} \mathrm{~V}$. Roberto Prado de Vasconcellos, "Provas ilicitas (enfoque constitucional", in Revista dos Tribunais, n" 791, sctembro de 2001. São Paulo, págs.456 e ss.
} 
A luta contra o crime organizado coloca em cheque garantias do Estado liberal ${ }^{27}$ e tem levado a lei, a doutrina e a jurisprudência brasileiras, como já ocorreu com a jurisprudência americana ${ }^{28}$, a serem complacentes com o desrespeito a direitos fundamentais, esquecendo-se que a nossa Constituição não prevê a suspensão individual de direitos fundamentais, a não ser da liberdade de locomoção por força de condenação criminal, e que a suspensão coletiva desses direitos somente pode ocorrer no estado de defesa ou no estado de sítio, ainda assim por tempo limitado (Constituição, arts. 136 e 138).

O modelo norte-americano é freqüentemente invocado ${ }^{29}$, como, por exemplo, na aceitação das provas ilícitas se for razoável supor que elas seriam de qualquer modo obtidas por meios lícitos, mas esse modelo não pode ser adotado como paradigma, pelo reduzido respeito que vota aos direitos da personalidade como limites à apuração da verdade.

Como ressalta VITTORIO DENTI, o problema das provas ilícitas não pode ser analisado no plano meramente processual, mas como garantia de respeito a direitos fundamentais protegidos por normas constitucionais ${ }^{30}$.

As provas derivadas das provas ilícitas (os chamados frutos da árvore venenosa) devem reputar-se igualmente ilícitas, sob pena de, por via indireta, acabar por legitimar-se o desrespeito a direitos fundamentais. Não se protegem direitos fundamentais suprimindo direitos fundamentais.

\section{Presunções}

$\mathrm{O}$ art. 334 do CPC, em linguagem imprópria, dispensa de prova os fatos notórios, os confessados, os incontroversos e aqueles em cujo favor milita presunção legal de existência ou veracidade.

Em todos esses casos não se pode dizer que tais fatos independam de prova. Em verdade, de um ou outro modo esses fatos terão sido objeto de alguma prova ou, se dispensada esta, aquele, contra o qual foram alegados, pode produzir provas da sua inexistência.

\footnotetext{
"Jean Pradel, "Les systèmes pénaux a l'épreuve du crime organise", Revista de Processo, ano 24, n"94, abril/junho de 1999 , ed. Revista dos Tribunais, págs. 155/175.

2 V. sobre a evolução da jurisprudência americana em materia de proxas líicitas, da Corte Warren à Corte Burger, Luigi Pado Comoglio, "Repressione del crimine ed inconstituzionalita dei mezzi di prova", in Rivista do Dintto Processuale, CEDAM, Padova, 1972, pags.589/618.

2" V. José Carlos Barbosa Moreira, "A Constituição as provas ilicitamente obtidas", in Temas de Direrio Processuat, 6o Série, Săo Paulo, 1997, págs. 107/12s.

30 Vitorio Dent, "Cientificidad de la prueba y libre valoración del juez", in Estudios de derecho probatorio, EJEA, Buenos Aires, 1974, pág.271
} 
Comecemos pelas presunções, que podem ser legais ou simples. Aquelas, resultantes da lei, por sua vez, podem ser absolutas (juris et de jure) ou relativas (juris tantum). As absolutas geram a certeza incontestável da existência do fato presumido, desde que provada a presunção. As relativas dispensam aqueles que alegam o fato presumido da produção de qualquer outra prova, exceto da própria presunção, mas invertem o ônus da prova, permitindo que o adversário ilida a eficácia da presunção através da produção de prova concreta da inexistência do fato presumido.

As presunções simples, humanas ou judiciais, são as ilações ou inferências extraídas com base em raciocínio indutivo a respeito da existência de algum fato probando a partir da prova da existência de algum outro fato que com aquele guarda alguma correlação, de acordo com as máximas da experiência comum (id quod plerumque accidit). Estas não estão previstas no art.334, mas de modo igualmente incorreto no art. 335, que parece reservá-las para as hipóteses de lacuna da lei, quando na verdade essas presunções, resultantes das máximas da experiência, são amplamente utilizadas no julgamento das questões de fato como critérios justificativos da aceitação da maior ou menor força persuasiva de todas as demais provas.

As presunçōes não são meios autônomos de prova, mas provas lógicas ou críticas produzidas através de quaisquer outros meios.

As presunções legais absolutas são verdadeiras normas de direito material que atribuem certos direitos em conseqüência de determinados fatos. Ao invés de atribuir a estes fatos diretamente o caráter gerador daqueles direitos, o legislador, por ficção, considera que eles provam de modo absoluto e incontestável a existência dos fatos que a lei considera geradores de tais direitos. Vai ser o direito material quem vai dizer se tais presunçôes são ou năo lícitas. Assim, por exemplo, no Direito Tributário, não se admitem presunções absolutas da ocorrência de fatos geradores de tributos, sob pena de surgimento da obrigação tributária sem o indispensável suporte fático, que é o fato econômico ${ }^{31}$.

\footnotetext{
3. Voão Dácio Rolim, "Consideraçöes sobre a Norma Geral Antielisiva Introduzida pela Lei Complementar 104/2001"; João Francisco Bianco, "Norma Geral Antielisão - Aspectos Relevantes": José Eduardo Soares de Melo, "Planejanento Trbutáto e a lei Complementar 104"; Marco Anelio Greco, "Constitucionalidade do Parágrafo Tnioo do Artigo 116 do CTN"; Misabel Abreu Machado Derzi, "A Desconsideraça dos Atos e Negócos Jurídicos Dissimulatórios, segundo a Lei Complementar $n^{\circ}$ 104, de 10 de janeiro de 2001 ", todos in O Planejamento tributáno a lei Complementar 104, coord. Valdir de Oliveira Rocha, ed. Dialética, São Palolo, 2002.
} 
As presunçôes legais relativas provocam uma inversão do ônus da prova, impondo ao adversário da parte à qual beneficiam o encargo de demonstrar a sua não ocorrência. Elas devem submeter-se aos requisitos de gravidade, precisão e concordância ${ }^{32}$, do contrário podem colocar a parte por elas beneficiada em situação extremamente vantajosa em relação ao seu adversário, por elas submetido ao ônus da prova de fatos freqüentemente inacessíveis ou de demonstração excessivamente onerosa. A própria presunção de legitimidade dos atos administrativos não mais prevalece no processo, em face dos princípios da legalidade, da impessoalidade e da moralidade, que regem a Administração Pública, de acordo com o art. 37 da Constituição, e que lhe impõem o dever de fundamentar os seus atos em fatos e provas concretos justificadores da causalidade adequada daqueles ${ }^{33}$.

As presunções simples, humanas ou judiciais, como já mencionei, são inferências extraídas pelo juiz das máximas da experiência comum, ou seja da correlação socialmente reconhecida entre certos fatos, os indícios, de acordo com os valores e os comportamentos habituais vigentes em determinada sociedade em determinado momento histórico. $O$ juiz aplica essas inferências não como jurista, mas como cidadão que vive dentro dessa sociedade ${ }^{34}$. Conforme prevê o art. 335 do nosso CPC, essas inferências abrangem a experiência técnica reconhecivel pelo juiz sem necessidade de exame pericial, como, por exemplo o fato de que o consumo freqüente de medicamentos de venda controlada sem receita médica é prejudicial à saúde.

Limitaçôes probatórias à prova indiciária submetem-se aos mesmos princípios das demais limitaçōes. Assim, por exemplo, a regra do art. 230 do novo Código Civil ("As presunções, que não as legais, não se admitem nos casos em que a lei exclui a prova testemunhal") vale apenas como uma recomendação ao juiz. Trata-se de restrição imposta para evitar a produção de provas supostamente suspeitas, mas que não pode constituir obstáculo à apuração da verdade, servindo apenas de advertência ao juiz da sua normal precariedade, a ser considerada na formação da livre convicção.

\footnotetext{
${ }^{32} \mathrm{O}$ requisito da concordância exige que concorram várias presunçöes que convirjam para a mesma conclusäo. Michele Taruffo ("Le prove", in Rivista Trinestrate di Diritto e Procedura Civile, Giuffè, Milano, ano XLIX, 1995, pág.1479) ressalta que a jurisprudência às vezes se satisfaz com apenas uma presunção, desde que grave e precisa.

${ }^{3}$ V. Paulo de Barros Carvalho, A Prova no Procedinento Administrativo Tributáno, in Revista Dialética de Dircito Tributário, 34/104; José Eduardo Soates de Melo, "Análise critica do processo administrativo fiscal no âmbito do Tribunal de Impostos e Taxa de Săo Paulo", in Processo Administrativo Fiscal, ed. Dialética, 1997; e Sérgio Ferraz e Adilson de Abreu Dallati, Processo Adninistrativo, ed. Malheiros, São Paulo, 2001, pág.137.
}

${ }^{34}$ Francesco P. Luiso, ob.cit., pág. 81. 


\section{Fatos notórios}

Notórios são os fatos cuja veracidade está sedimentada na consciência coletiva de uma determinada sociedade, da qual façam parte o juiz e as partes, em determinado local, em determinada época. É comum a doutrina aliar a notoriedade à cultura do homem médio ${ }^{35}$, mesmo que o juiz e as partes não façam parte da comunidade em que o fato adquiriu notoriedade.

Hoje, entretanto, para não contrariar as garantias do contraditório e da ampla defesa, a notoriedade também deve ter fundamento na experiência comum, mas não apenas do juiz, e também de ambas as partes. Notórios são os fatos que, depois de ocorridos, foram devidamente comentados, dissecados pelos membros de uma determinada coletividade em razão de sua particular importância, de tal modo que se sedimentou na consciência dessa sociedade a veracidade desse fato, com determinadas circunstâncias.

A consciência coletiva do fato notório deve ser durável, pelo menos pelo tempo de duração do processo em que o fato foi alegado e tido como verdadeiro. Por isso, o fato notório há de ser relevante, não efêmero, mas um daqueles fatos que efetivamente repercutiu na vida da coletividade.

A legitimidade da dispensa da prova do fato notório resulta dessa relevância, bem como da participação dos três sujeitos principais do processo da comunidade em que o fato adquiriu tal repercussão. Se uma das partes não faz parte dessa coletividade, não pode ser atingida pela veracidade de fato que desconhece. Se o juiz não faz parte dessa coletividade, não pode ser obrigado a reconhecer como verdadeiro fato improvado. Exigir a prova da notoriedade seria o mesmo que reconhecer que o fato não é notório.

Mas não é correta a afirmação do art. 334 do CPC de que o fato notório não depende de prova, porque aquele contra o qual for reconhecida a notoriedade de um fato pode impugná-lo e provar a sua inexistência, caso em que a parte que o alegou pode também produzir provas em favor da sua existência. Simplesmente, aquele a quem tal fato beneficia fica provisoriamente dispensado de demonstrar concretamente a sua ocorrência, presumida pela notoriedade.

is V. Moacyt Amaral Santos, Prowa Judiciaria, pág. 169. 


\section{Fatos confessados e incontroversos}

Com indiscutível razão os cultores de outros ramos do Direito, especialmente do direito material, criticavam o processo científico pelo formalismo e pela sua infinita capacidade de criar artifícios para conduzir o julgador a qualquer resultado. Sintoma desse artificialismo são as regras dos incisos II e III do art. 334 do CPC, que dispensam a prova dos fatos confessados e daqueles admitidos como incontroversos. Nas causas sobre direitos disponíveis, se as partes podem dispor desses direitos, podem dispor dos fatos dos quais eles poderiam ser extraídos. Assim, os fatos confessados pela parte a quem prejudicam ou reconhecidos como incontroversos se reputariam verdadeiros, não devendo o juiz determinar a produção de qualquer prova para demonstrá-los.

Essa concepção, entretanto, não pode mais prevalecer, porque a liberdade de consciência do juiz e a credibilidade das suas decisões não podem contentar-se com a presumível veracidade de fatos absolutamente inverossímeis, simplesmente como conseqüência da confissão ou da inércia da parte a quem prejudicam.

A confrança que os cidadãos depositam na justiça depende da sua crença em que os juízes decidem as causas que lhes são submetidas de acordo com a verdade fática por todos aceita e objetivamente apurada, $e$ não apenas com base em fatos reputados como verdadeiros porque confessados ou não impugnados, embora despidos de qualquer verossimilhança.

Se o autor afirma um fato contrário ao senso comum, como por exemplo que se encontrou com o réu na Lua no último Carnaval, o juiz não vai aceitar tal fato como verdadeiro simplesmente porque confessado ou não contestado pela parte contrária. A chamada verdade formal, que resulta do entrechoque das alegações das partes, não pode ser uma manifesta inverdade. Se o fato for relativamente inverossímil, deverá o juiz determinar que as partes concretamente o comprovem, o que demonstra continuar ele a ser objeto de prova. Se for absolutamente inverossímil, de nada adiantarão a confissão ou a sua não impugnação no processo. 


\section{Confissão}

Que significado pode ter na atualidade a regra do art. 350 do CPC, segundo a qual "a confissão faz prova contra o confitente"? Seguramente, em face dos comentários feitos no item anterior, não pode mais cogitar-se de considerá-la prova plena, mas apenas a de gerar uma presunção relativa de veracidade dos fatos desfavoráveis ao confitente, que pode ser destruída por provas em contrário.

Também a confissão extrajudicial sofreu nestes trinta anos enorme evolução. Não é mais possível simplesmente equipará-la à judicial, como o faz o art. 353, na dependência apenas da forma escrita e do destinatário, no caso a parte contrária. Essa regra retrata uma máxima da experiência possivelmente vigente à época do Código. Quem confessa por escrito ao próprio beneficiário, quer colocá-lo em posição de vantagem em qualquer futura demanda judicial. Todavia a realidade da vida mudou. Hoje existem na sociedade muitas relações de dominação. Pessoas que se encontram em posição de vantagem impõem facilmente a sua vontade. Aqueles que com elas negociam se sentem induzidos a confessar fatos desfavoráveis para com elas poderem manter relações jurídicas e negócios. O mais fraco é induzido a uma confissão extrajudicial, porque dela depende um benefício imediato, como o parcelamento do débito fiscal, por exemplo, necessário para a continuidade ou o êxito dos seus negócios. Essa confissão extrajudicial não pode impedir que o confitente, num futuro processo judicial, produza provas concretas da inexistência dos fatos anteriormente reconhecidos como verdadeiros.

O art. 214 do novo Código Civil dispõe que a confissão é irrevogável. Trata-se de evidente confusão com a renúncia ou o reconhecimento do direito, pois "não se confessa a dívida, a relação jurídica; confessam-se fatos" 36 , que continuam objeto de prova, embora a confissão gere uma presunção de veracidade dos fatos confessados.

Quanto ao depoimento pessoal, MAURO CAPPELLETTI teve a oportunidade de demonstrar ${ }^{37}$ que os sistemas processuais da família da civil law sacrificam pelo risco da suspeição a prova mais apta a revelar a verdade ao juiz, o depoimento pessoal das partes, cuja eficácia fica restrita às declarações que lhes são desfavoráveis.

\footnotetext{
36 Pontes de Miranda, Comentários ao CPC tomo N, $3^{\circ}$ ed., Forense, Rio, 1996 , pág.315.

${ }^{37}$ Mauro Cappelletti, La testimonianza della parte nel sistema dell'onhita, ristampa, Giuffre, Muano, 1974.
} 
A necessidade de instaurar no processo um diálogo humano, como instrumento do contraditório participativo, leva esses sistemas a buscar subsídios nos países da common law, que, através da cross examination, submetem a parte à inquirição do seu próprio advogado, transformando o interrogatório em instrumento de auto-defesa. É o sistema do chamado interrogatório livre, em que a parte não se limita a responder às perguntas do juiz, mas tem oportunidade de com ele dialogar e assim contribuir de forma mais eficaz na reconstituição dos fatos, ao mesmo tempo em que dele faz uso como instrumento de sua própria defesa.

No Código de 73, o depoimento pessoal não perdeu ainda o seu caráter meramente negativo de instrumento de confissão, a exigir urgente reformulação para harmonizá-lo com as garantias fundamentais do processo, especialmente com as do contraditório e da ampla defesa.

\section{Prova documental}

A prova documental vive hoje a sua grande crise de identidade, provocada com o surgimento do chamado documento eletrônico. Já tive oportunidade de apontar alguns aspectos dessa revolução, que ainda geram perplexidade no mundo jurídico ${ }^{38}$.

Mesmo em países que já adotaram uma legislação própria para a matéria, como por exemplo a Itália, com a chamada Lei Bassanini ${ }^{39}$, ainda perduram grandes incertezas quanto ao procedimento para a verificação da sua autenticidade, assim como para a argüição da sua falsida$\mathrm{de}^{40}$, e ainda sobre a possibilidade de uma perícia constatar com grau de certeza a sua adulteração.

A falta de assimilação em nosso Direito da consciência de um direito genérico à informação fragiliza a produção da prova documental como direito subjetivo processual, subordinando as partes, em matéria de exibição, ao "prudente arbítrio do juiz", conforme reconhecido pelo próprio legislador (CPC, art. 363-V).

\footnotetext{
23. V. o meu "O Processo Eletrônico", in Internet e Direito - Reffexốes Doutrinánias, ed. Lumen Juris, Rio de Janeiro, 2000, págs.11/31; também publicado in Direito e Internet - Relaçós Juridicas na Soctedade Informatzadt, coord. Ives Gandra da Silva Martins e Marco Aurelio Greco, ed Revista dos Tribunais, São Paulo, 2001, págs. 77/94.

39 Lei n" 59 de 15 de marco de 1997.

in Giovanni Verde, Prothl del Processo Civile, 2" vol., $2^{\circ}$ ed., Jovene, Nápoli, 2000, págs.105/106.
} 
Por outro lado, uma disciplina primária e superficial dos direitos da personalidade no novo Código Civil pode indevidamente ensejar mais intensas restrições à utilização da prova documental, em prejuízo da apuração da verdade, como conseqüência da aplicação do disposto no seu art. 20, que, dificultando a divulgaçăo de escritos de uma pessoa, parece ignorar por completo a relevância que possuem na prova das relações econômicas os escritos de terceiros.

\section{Prova testemunhal}

A prova testemunhal é a que apresenta o maior número de limitações ao dircito de defender-se provando è busca da verdade: restrições ao seu uso (CPC, arts. 400 e 401; novo Código Civil, art.227); restrições ao depoimento de pessoas incapazes, impedidas ou suspeitas (CPC, art.405), escusas de depor (art. 406), número máximo de testemunhas (art. 407, parágrafo único), restrições à substituição de testemunhas (art.408).

$\mathrm{O}$ assunto mereceria um estudo à parte, mas desde logo parece-me que a aplicação dessas regras deve observar o que dissemos sobre as limitações probatórias (item 8 , acima), devendo ter-se como meras recomendações ditadas pelas máximas da experiência as que visam a evitar a produção de provas suspeitas. Seguindo essa orientação, o art. 228 do novo Código Civil, mais amplamente do que o art 405 do CPC, permite o depoimento de pessoas incapazes, impedidas ou suspeitas, para a prova de fatos que só elas conheçam.

Quanto ao limite numérico e à proibição de substituição, que representam verdadeiras preclusões, penso que é indispensável deixar de aplicálos quando houver motivos imperiosos, alheios à vontade da parte, que impediram que a parte se ativesse estritamente à observância dessas regras, para não prejudicar a mais ampla defesa.

Por outro lado, as acareações e depoimentos de testemunhas referidas não podem mais ser entendidos como simples faculdades do juiz, passando a integrar o direito à prova e, portanto, devendo ser deferidas com tolerância, salvo em caso de manifesta inutilidade.

Os depoimentos por meios de telecomunicação, como a internet ou videoconferências, podem ser aceitos, graças ao princípio da liberdade das formas, desde que, cumulativamente, a cognição seja qualitativamente igual ou superior à do meio legal de prova, não haja qualquer ofensa à 
dignidade humana ou desrespeito aos direitos e garantias fundamentais e a forma adotada não diminua a credibilidade desses depoimentos ${ }^{41}$.

Medidas de proteção à testemunha, usadas no combate ao crime organizado, devem ser questionadas do ponto de vista humanitário e da garantia constitucional da plenitude de defesa, na medida em que privem a parte contra a qual o depoimento é produzido do direito de conhecer a identidade de quem a acusa e, assim, de apurar a sua idoneidade e o valor das suas declarações, ou que impeçam a presença do acusado ao depoimento do acusador, suprimindo a auto-defesa e o direito de influir no seu depoimento através das reperguntas.

\section{Prova científica}

Os avanços e recuos do ordenamento processual em matéria de prova pericial dão bem a medida da insatisfação da comunidade jurídica com a referida prova e da insuficiência da sua disciplina como instrumento eficaz de busca da verdade.

Dos peritos escolhidos pelas partes e o desempatador escolhido pelo juiz no regime do Código de 39 , a sistema do perito único escolhido pelo juiz no Código de 73 com a colaboração de assistentes técnicos imparciais escolhidos pelas partes, rendeu-se a Lei 8.455/92 à triste realidade da falta de isenção dos assistentes técnicos para excluí-los do rol de sujeitos imparciais e para dispensar o perito oficial do diálogo com esses auxiliares.

O temor dos advogados em relação à ditadura do perito se concretizou. No momento em que o juiz escolhe o perito, a confiança que nele deposita pode implicar com freqüência em verdadeira delegação da jurisdição sobre a matéria técnico-científica. Pouca ou nenhuma influência na decisão judicial têm os pareceres críticos dos assistentes-técnicos das partes, agora oficialmente parciais, tendenciosos e apresentados somente depois que o perito do juizo já apresentou as suas conclusões. O próprio juiz se torna presa das conclusões da perícia, pela impossibilidade de controle da sua credibilidade, o que, segundo RICCI, acaba por transformar a perícia numa prova legal, que se sobrepõe à própria livre conviç̧ão $\mathrm{O}^{42}$.

A introdução da perícia por depoimento oral $\left(\mathrm{CPC}\right.$, art. $\left.421, \S 2^{\circ}\right)$, parcial importação do sistema da common law, não vingou. Não é da nossa tradição.

\footnotetext{
"V. o neu "O Procssso Eletrônico".

tr. Ob.cit., pág. 1151 .
} 
O novo Código Civil é absolutamente omisso sobre esse importante meio de prova, dispondo apenas nos arts. 231 e 232 a respeito de presumíveis efeitos da recusa à perícia médica.

A busca da verdade objetiva no processo deve determinar a progressiva aproximação dos seus métodos de investigação científica dos métodos da própria ciência ${ }^{43}$. A ciência revelada no processo deve ser tão confiável quanto a que é investigada nas universidades, nos laboratórios e centros de pesquisa, com a mesma credibilidade e confiabilidade. Para tanto, é preciso rever o sistema de produção da prova pericial para que: 1) a pessoa ou órgão (e a nossa lei somente prevê a perícia pessoal) que vá produzir a perícia revele a sua aptidão para revelar o conhecimento científico necessário para a decisão judicial; 2) ao juiz sejam oferecidas as informações necessárias a verificar se o método empregado na perícia é acatado pela ciência, se foi utilizado com rigor científico e, no caso de assunto cientificamente polêmico, quais são as alternativas científicas e o seu grau de confiabilidade; 3) as partes, por si ou por seus assistentes-técnicos, assim como terceiros que possam trazer contribuições desinteressadas para a revelação da verdade científica (amici curiae), possam efetivamente participar na produção do conhecimento científico no processo e o juiz seja obrigado a utilizar meios e critérios reconhecidos pela ciência para resolver as dúvidas e divergências entre as opiniões apresentadas.

Nos Estados Unidos desde o início da década de 90, especialmente após o julgamento pela Corte Suprema do caso Daubert em $1993^{44}$, e mais recentemente também na Europa, desencadeou-se um grande debate nos meios acadêmicos e judiciais a respeito da necessidade de controle judicial da confiabilidade da prova científica.

Grande parte dos estudos e análises científicos utilizados nos processos judiciais são o que se poderia chamar de provas estatísticas, ou seja, métodos empíricos de observação de fatos que em grau elevado têm revelado coincidências, permitindo extrair da existência de uns a provável existência de outros. Perícias contábeis, testes de DNA, laudos sobre danos ambientais ou sobre a nocividade de produtos entregues ao consumo, por exemplo,

\footnotetext{
${ }^{+3}$ Michele Taruffo observa ("Elementi per un'analisi del giudizio di fatto", in Sui confini - scritti sulla giastizia civile, Il Mulino, Bologna, 2002, pág.269) que talvez a diferença mais relevante entre o conbecimento científico e o conhecimento judiciário é que naquele a seqüência de atos de aquisição probatória é infinita, enquanto neste a seqüência é finita, porque o processo precisa terminar.

+4 Daubert v. Merrell Dow Pharmaceuticals, Inc., sentença da Corte Suprema dos Estados Unidos de 28/6/ 1003, rel. Blackmun, in Angelo Dondi, 'Paradigmi processuali ed 'expert witness testimony' nel diritto statunitense", in Rivista Trimestrale di Diritto e Procedura Civile, Giuffrè, Milano, ano L, 1996, págs.277/285.
} 
nada mais são do que provas estatísticas, cuja confiabilidade sempre apresenta alguma margem de erro e depende essencialmente da aplicação rigorosa das regras de segurança do método científico de realização desses estudos ${ }^{45}$. Como juízos de probabilidade, e não de certeza, por mais reduzida que seja a sua margem de erro, não podem jamais ser tidos como prova plena. Além da necessária verificação pelo juiz dos seus pressupostos metodológicos, que é totalmente omitida entre nós, deve o juiz sempre admitir a produção da contra-prova, que nunca pode ser considerada inútil.

Em recente artigo publicado no jornal Folha de S.Paulo ${ }^{46}$, LUIZ FERNANDO JOBIM, professor de Medicina da Universidade Federal do Rio Grande do Sul, denunciou a inobservância do método apropriado em inúmeros exames de DNA realizados no Brasil e possíveis erros em seus resultados.

\section{Conclusão}

Que dizer, à guisa de conclusão, trinta anos depois, do sistema probatório do Código de Processo Civil de 1.973?

Primeiramente, que o novo Código Civil em muito poucos pontos o aprimorou, porque, fruto da mesma época, não foi capaz de compreender o papel democrático reservado ao processo judicial como instrumento de eficácia concreta de direitos no Estado de Direito Contemporâneo.

Em segundo lugar, dizer que a maior parte das regras disciplinadoras da prova judiciária do Código de 1.973 ainda sobrevivem, mas não mais com a mesma força. Perderam a eficácia de dirigirem a conduta do juiz, para somente a influenciarem.

Mas, além e acima do Código, sobrepairam, como desafio à reflexão dos doutos, grandes problemas decorrentes da elevação da prova à dignidade de componente essencial do direito de acesso à justiça e da necessidade de torná-la instrumento eficaz de busca da verdade, tão objetiva e confiável como a verdade histórica e a verdade científica.

Alguns desses problemas foram aqui brevemente mencionados e deverão merecer reflexão aprofundada no futuro. E no campo das provas que o processo pode aproximar-se da realidade da vida, contribuindo para que a Justiça consiga dar razão a quem tem direito e, mesmo quando não o fizcr, para que a sociedade possa nela confiar, por ter feito o máximo possível para realizar esse ideal.

\footnotetext{
;. $\mathrm{V}$. Andrea Giussani, "La prova statistica nelle "dass actions", in Rivista di Dirito Processiale, CEDAM, Patova, 1989, pás.1029 \&s.; Michele Taruffo, "Le prove scientifiche nella recente esperienza staturixtense" in Rivista Trimestrale di Dirito e Procedura Civile, Giuffrè, Milano, ano L, 1996, págs. 219/249; Angelo Dondi, "Problemi di utilizzazione delle 'conoscenze esperte' come 'expert witness testimony' nell'ordinamento statunitense", in Rivista Trimestralc di Divito e Procedura Cirile, Guffrè, Milatio, ano $L V, 2001$, págs. 1133/1162.

"w "Testes de DNA", in Folha de S.Paulo, 26/2/2002, caderno A, pág.3.
} 


\section{BIBLIOGRAFIA}

AROCA, J. M. et alii. Derecho Jurisdiccional, vol. II, $10^{\circ}$ ed., Tirant lo Blanch, Valencia, 2001.

AROCA, J. M. Los princípios políticos de la nueva Ley de Enjuiciamiento Civil- Los poderes del juez y la oralidad. Valencia: Tirant lo Blanch, 2001. BIANCO, J. F. Norma Geral Antielisão - Aspectos Relevantes. In: ROCHA, V. de O. (coord). O Planejamento tributário e a Lei Complementar 104. São Paulo: Dialética, 2002.

CAPPELLETTI, M. La testimonianza della parte nel sistema dell'oralità, ristampa, Giuffrè, Milano, 1974.

CAPPELLETTI, M. Procedure Orale et Procedure Ecrite, Giuffrè, Milano, 1971 CARVALHO, P. de B. A Prova no Procedimento Administrativo Tributário. In: Revista Dialética de Direito Tributário, 34/104.

COMOGLIO, L. P. Repressione del crimine ed inconstituzionalità dei mezzi di prova. In: Rivista do Diritto Processuale, CEDAM, Padova, 1972.

DAUBERT V. MERRELL DOW PHARMACEUTICALS, Inc., sentença da Corte Suprema dos Estados Unidos de 28/6/1003, rel. Blackmun, in Angelo Dondi, "Paradigmi processuali ed 'expert witness testimony' nel diritto statunitense", in Rivista Trimestrale di Diritto e Procedura Civile. Giuffrè, Milano, ano L, 1996.

DENTI, V. Cientificidad de la prueba y libre valoración del juez. In: Estudios de derecho probatorio. Buenos Aires: EJEA, 1974.

DENTI, V. La evolución del derecho de las pruebas em los procesos civiles contemporáneos, In Estudios de derecho probatorio. Buenos Aires: EJEA, 1974. DERZI, M. A. M. A Desconsideração dos Atos e Negócios Jurídicos Dissimulatórios, segundo a Lei Complementar $\mathrm{n}^{\circ}$ 104, de 10 de janeiro de 2001. In: ROCHA, V. de O. (coord). O Planejamento tributário e a Lei Complementar 104. São Paulo: Dialética, 2002.

DONDI, A. Problemi di utilizzazione delle 'conoscenze esperte' come 'expert witness testimony' nell'ordinamento statunitense. In: Rivista Trimestrale di Diritto e Procedura Civile. Giuffrè, Milano, ano LV, 2001.

FERRAZ, S.; DALLARI, A. de A. Processo Administrativo. São Paulo: Malheiros, 2001.

FUX, L. Tutela de Segurança e Tutela da Evidência. São Paulo: Saraiva, 1996. GIUSSANI, A. La prova statistica nelle 'class actions'. In: Rivista di Diritto Processuale, CEDAM, Padova, 1989. 
GRECO FILHO, V. Direito Processual Civil Brasileiro, $2^{\circ}$ vol., $15^{\circ}$ ed., São Paulo: Saraiva, 2002.

GRECO, L. Garantias Fundamentais do Processo: o Processo Justo. In: Revista Jurídica. São Paulo: Notadez, ano 51, março de 2003, n 305.

GRECO, L. O Processo Eletrônico. In MARTINS, I. G. da S.; GRECO, M. A. (coord.). Direito e Internet - Relaçōes Jurídicas na Sociedade Informatizada. São Paulo: Revista dos Tribunais, 2001.

GRECO, L. O Processo Eletrônico. In: Internet e Direito - Reflexões Doutrinárias. Rio de Janeiro: Lumen Juris, 2000.

GRECO, M. A. Constitucionalidade do Parágrafo Único do Artigo 116 do CTN. In: ROCHA, V. de O. (coord). O Planejamento tributário e a Lei Complementar 104. São Paulo: Dialética, 2002.

LUISO, F. P. Diritto Processuale Civile, vol.II, $3^{\circ}$ ed., Giuffrè, Milano, 2000. MELO, J. E. S. de. Planejamento Tributário e a lei Complementar 104. In: ROCHA, V. de O. (coord). O Planejamento tributário e a Lei Complementar 104. São Paulo: Dialética, 2002.

MELO, J. S. de. Análise crítica do processo administrativo fiscal no âmbito do Tribunal de Impostos e Taxa de São Paulo. In: Processo Administrativo Fiscal. São Paulo: Dialética, 1997.

MONTEIRO, C. S. Teoria da Argumentação Jurídica e Nova Retórica, $2^{\underline{o}}$ ed., Rio de Janeiro: Lumen Júris, de Janeiro, 2003.

MOREIRA, J. C. B. A Constituição e as provas ilicitamente obtidas. In:Temas de Direito Processual, $6^{\circ}$ Série, São Paulo: 1997.

MOREIRA, J. C. B. O novo Código Civil e o Direito Processual. In Revista Forense, $n^{2}$ 364, Rio de Janeiro: Forense, 2003.

PONTES DE MIRANDA. Comentários ao CPC, tomo IV, $3^{\circ}$ ed., Forense, Rio, 1996.

PRADEL, J. Les systèmes pénaux à l'épreuve du crime organisé. In: Revista de Processo, ano 24, n 94, abril/junho de 1999, São Paulo: Revista dos Tribunais, 1999.

RICCI, G. F. Nuovi rilievi sul problema della 'specificità' della prova giuridica. In Rivista Trimestrale di Diritto e Procedura Civile, ano LIV, 2000, Giuffrè, Milano.

ROCHA, V. de O. (coord.). O Planejamento tributário e a Lei Complementar 104. São Paulo: Dialética, 2002.

ROLIN, J. V. Considerações sobre a Norma Geral Antielisiva Introduzida pela Lei Complementar 104/2001. In: ROCHA, V. de O. (coord). O Planejamento 
tributário e a Lei Complementar 104. São Paulo: Dialética, 2002.

SANTOS, M. A. Comentários ao Código de Processo Civil, IV vol., $2^{\circ}$ ed., Rio de Janeiro: Forense, 1977.

SANTOS, M. A. Primeiras linhas de Direito Processual Civil, $2^{\circ}$ vol., $3^{\circ}$ ed., São Paulo: Saraiva, 1977.

SANTOS, M. A. Prova Judiciária no Cível e Comercial, vol. I, s/d, São Paulo: Max Limonad.

TARUFFO, M. Elementi per un'analisi del giudizio di fatto. In: Sui confini scritti sulla giustizia civile, Il Mulino, Bologna, 2002.

TARUFFO, M. La prova dei fatti giuridici, Giuffrè, Milano, 1992

TARUFFO, M. Le prove scientifiche nella recente esperienza statunitense. In: Rivista Trimestrale di Diritto e Procedura Civile. Giuffrè, Milano, ano L, 1996.

TARUFFO, M. Lezioni sul processo civile, $2^{\circ}$ ed., Il Mulino, Bologna, 1998. TARUFFO, M. Modelli di prova e di procedimento probatorio. In Rivista di Diritto Processuale, CEDAM, Padova, 1990.

TARUFFO, M. Presunzioni, inversioni, prova del fatto, In Rivista Trimestrale di Diritto e Procedura Civile, Giuffrè, Milano, ano XLVI, 1992.

TROCKER, N. Il contenzioso transnazionale e il diritto delle prove. In Rivista Trimestrale di Diritto e Procedura Civile, ano XIVI, 1992, Giuffrè, Milano. TROCKER, N. Processo Civile e Costituzione, Giuffrè, Milano, 1974 VASCONCELLOS, R. P. de. Provas ilícitas (enfoque constitucional). In: Revista dos Tribunais, $n^{\circ}$ 791, São Paulo: Revista dos Tribunais, setembro de 2001. VERDE, G. Profili del Processo Civile, $2^{\circ}$ vol., $2^{\circ}$ ed., Jovene, Nápoli, 2000. 